\title{
From fertility rituals to mining companies: eco- cultural issues and land rights in Oksapmin
}

\section{Lorenzo Brutti}

\section{(2) OpenEdition \\ 12 Journals}

\section{Electronic version}

URL: http://journals.openedition.org/jso/979

DOI: $10.4000 /$ jso. 979

ISSN: $1760-7256$

\section{Publisher}

Société des océanistes

\section{Printed version}

Date of publication: 1 December 2007

Number of pages: 249-255

ISBN: 978-2-85430-010-9

ISSN: 0300-953x

\section{Electronic reference}

Lorenzo Brutti, «From fertility rituals to mining companies: eco-cultural issues and land rights in Oksapmin », Journal de la Société des Océanistes [Online], 125 | Année 2007-2, Online since 01 December 2010, connection on 01 May 2019. URL : http://journals.openedition.org/jso/979 ; DOI $10.4000 /$ jso. 979

\section{(c) Tous droits réservés}




\title{
From fertility rituals to mining companies: eco-cultural issues and land rights in Oksapmin
}

by

\author{
Lorenzo BRUTTI*
}

\begin{abstract}
This paper describes the Oksapmin representations of land ownership related to the frame of the water use permit payment process, engaged by Porgera Joint Venture (PJV) as a consequence of the ecological impact of the mine operations on the Lagaip-Strickland basin. Even if the Oksapmin society has been fully evangelized during the last two generations, the landowners have recently stressed the pre-contact exegesis in the claims against that foreign mining company. In this essay the author formulates the hypothesis that the claims to the former animist beliefs may be a social strategy to manage land ownership. This strategy provokes, on the side of private companies, a monetary compensation for the " eco-cultural » impact of mining operations. The land issues focus today on the rediscovery of tradition in order to integrate it to modernity. Tradition then acquires a new original rule in contemporary society. The water spirits and the river sacred sites are re-interpreted and perceived as the guardians of land rights, held by mythical actors at the beginning of time.
\end{abstract}

KeYWORDS: Oksapmin, Mining companies, Ethnoecology, Religious change, Land rights.

In Oksapmin (Sandaun Province, Papua New Guinea) representations of land ownership are

\section{RÉSUMÉ}

Cet article traite des représentations oksapmin de la propriété foncière en relation avec le paiement des compensations liées au permis d'usage des eaux engagées par Porgera Joint Venture (PJV) comme une conséquence de l'impact écologique des opérations de cette compagnie sur le bassin riverain du Lagaip-Strickland. Malgré le fait que la communauté oksapmin soit complètement évangélisée depuis les deux dernières générations, les propriétaires fonciers ont récemment mis en valeur l'exégèse pré-contact dans les récriminations qui les opposent aux compagnies minières étrangères. Dans cet article, l'auteur avance l'hypothèse que le retour à la revendication des anciennes croyances animistes soit une stratégie sociale pour gérer les droits fonciers. Cette stratégie entraîne en fait, de la part des compagnies privées, un dédommagement financier pour l'impact écologique et culturel des opérations minières. Poussés par les enjeux fonciers, les Oksapmin tendent aujourd'hui à redécouvrir la tradition pour l'intégrer à la modernité. La tradition retrouve ici un rôle nouveau et original. Les esprits aquatiques et les sites sacrés du fleuve sont réinterprétés et perçus comme les gardiens des droits fonciers, détenus par des acteurs mythiques à l'origine des temps.

MotS-CLÉS : Oksapmin, compagnies minières, ethnoécologie, changement religieux, droits fonciers.

narrowly related to the frame of the water use permit compensation payment process engaged

* CNRS CREDO, umR 6574, Marseille, lorenzo.brutti@pacific-credo.fr 
by Porgera Joint Venture (PJV) because of the ecological impact of the mine companies operations on the Lagaip-Strickland basin. The hypothesis I would like to develop here is that in the fully evangelized oksapmin community, people are rediscovering pre-Christian exegesis of land rights in order to gain compensation for the ecological impact of mining operations on their land.

The compensation rules have been drafted by the company itself. The amount of money the landowners get by the company is a function of the annual amount of waste and tailings from the mine in to the river basin divided by the linear surface of riverbanks. In simple terms, the heavier the pollution, the bigger the compensation. Moreover, the bigger the landownership (i.e. the clan have more land on the riverbanks), the greater the compensation this clan will get at the end of the year. Furthermore, the smaller the population of the clan, the more money the individuals will receive.

When the company first paid compensation in 1999, following mine and others anthropologists survey, the oksapmin landowners clan received a huge amount of money calculated upon almost ten years of mining. Indeed, mining operations started in Porgera in the early 1990s and, so in their first payment, the landowners received all financial reparations due from this time.

The mechanism of calculating and paying compensations was accepted with difficulty by most of oksapmin people. When, the following year, the oksapmin landowners naturally got a lighter compensation compared to the previous one (since that amount was only calculated for the current year), the company was severely criticized by the landowners. Furthermore, the company was also criticized for its choice to only pay the riverbanks' landowners. The other oksapmin clans, who had no land on the riverbanks but just on the oksapmin ridges and Highlands (Gaua, Trangap, Tekin, Bak) claim their right to be compensated too. Indeed they stressed the ritual and cosmological links which, on a traditional base, connected all of the oksapmin clans who performed both initiation and other collective ceremonies together. That was because the oksapmin clans conceived themselves as sharing the same cosmology and the same beliefs centered on Yuan-ku (Afek) mythical complex, as well as a characteristic stock of ritual practices.
In that frame, claiming a cultural, ritual, and cosmological homogeneity originated in the precontact era, was a social strategy in order to request the mining company to equally compensate the Oksapmin as a whole group and not just to privilege the landowners clan, following a western logic.

\section{An overview on Oksapmin development}

Evangelization started when the Australian Baptist Mission Society (ABMS) settled in Oksapmin in 1961. Before this time oksapmin people had irregular contact with westerners ${ }^{1}$. The monetarization process began in Oksapmin during the late 1960's and early 1970's due to outgoing laborers moving towards the coastal copra and coffee plantations. Thanks to monetarization and aerial links, oksapmin people began to travel quite often to urban centers (Tabubil, Hagen, Port Moresby, etc.) for work or occasional trips.

Nowadays many Oksapmin, mainly men, are employed by the mine companies settled in the area notably Ok Tedi Mining Limited. Tabubil is today the most important mine centre whose population is partly composed of hundreds of informal residents, who are relatives of the mine workers coming from Oksapmin.

The three main sources of income for community members, still living at home, are, in order of importance:

1) Growing vegetables to be sold to the mine consortiums (roughly $70 \%$ of cash income);

2) Remittances from relatives working in Tabubil (roughly $30 \%$ of cash income);

3) Occasional work involving maintenance of governmental structures (airstrips, roads).

The three main uses which locals currently make of their land are, in order of importance:

1) Gardening, including fallows area (roughly $80 \%)$

2) Hunting (roughly $15 \%$ )

3) Gathering (roughly $5 \%$ )

Concerning the non-labored land, it could be estimated that 30 to $50 \%$ of the community's land is presently covered by primary forest. These forest areas have not been tilled during the last century due to strong beliefs concerning chthonian spirits. In fact, convictions about primary forest as being inhabited by chthonian forces which are to be respected, prevent oksapmin

1. The first documented contact of Westerners with oksapmin people was made by James Taylor in August 1938. During this first contact, four oksapmin men died, killed by the patrol policemen to ward off a suspected attack. Due to the problems the first patrol had with the natives but also to the geomorphology of the oksapmin territory, the first Australian settlement of the area was established in Telefolmin. 
farmers to open gardens on these areas. This attitude remained at least until the male initiations where performed. Last initiation rituals took place in 1970 but since then have been stopped through active ostracism by the ABMS, who settled in Tekin valley since the 1960s.

Nowadays, because of the abandonment of those rituals the oksapmin agricultural practices have deeply changed and lost their traditional, pre-contact significance. In further decades, when all initiated men will be deceased, no one will be capable of transmitting the ecological knowledge concerning the environment. Unfortunately, that period will coincide with the end of the mine companies operations now settled around the oksapmin region. During this time a large number of mine workers will probably have to return to village life and base their livelihood on agroforestry. These people will not have the ecological competence of their grandfathers.

\section{Land management issues}

In oksapmin history there has been a type of traditional behavior directed towards the conservation of natural land resources: the paramount ritual of fertility called Yuan-hän based on a human sacrifice (see Brutti, 1997). People recognized different types of sacred sites, ceremonial houses and mythical foot tracks related to the Yuan hän ritual. Several of these sacred sites are located on the Strickland riverbanks.

With the massive conversion to Christianity in the 1970's, all ceremonial houses were destroyed during the process of Evangelization and portions of forest which were once forbidden for gardening started to be cultivated. Today, from the general oksapmin point of view, there is little concern about the forest and the environmental protection it provides, whereas the river basin environment is considered to be in danger due to erosion and chemical pollution. People take little care of the environmental conservation policy. It seems they believe that land resources are unlimited in space and time.

Also historically there is no similar situation with which things can be compared. In the past decisions about land use were made by the traditional leaders of the clans (kak hän), who owned the portion of land involved. Today, the advice of young educated Oksapmin, especially students of agroforestry, is taken into consideration. Examples of disputes I repeatedly witnessed concerned disagreements about boundaries, that don't necessarily involve large amounts of money or extensive gardening areas.
When unanimity is hard to find people go and ask mediation from the Officer in Charge (OIC) who will then appeal to competent elders to decide about the dispute. For example, in one case of disagreement about the boundary of a clan territory, an elder was able to explain that the mistake in defining boundaries was due to the deviation, several decades before, of the stream used as landmark of that territory.

Elders are more concerned than young people regarding land tenure and forest conservation and furthermore among the young people, educated youths are much more concerned than village youths. Within the acculturated Oksapmin, mine workers are the least concerned about land rights probably because, living in town, they are not directly dependant on forest resources. The behavior of those oksapmin agriculturists unconcerned with the environment is to cut larger portions of primary forest and to reduce the fallowing period during times of regrowth. This behavior is also due to the important demographic increase in Oksapmin during the last decades, which has reduced the quantity of gardening land per person.

Older people are particularly interested in land ownership. Land ownership, as a way to monetarization and to market economy, has mainly been pursued by the generations brought up since the early sixties, within contact of the Australian administration. Young men belonging to those generations were the first to leave for Rabaul and Madang plantations during the early seventies. This same process has repeated itself starting from the early eighties to the present by oksapmin men going to work in the mine centre of Tabubil. Land ownership is seen through the lens of economic, technological, social and religious change.

The discourse about land ownership is gender oriented in Oksapmin, in the sense that it is mainly held by men, not by women. This is a consequence of prevalent male education and immigration. Women have not migrated as workers, none hold university degrees while very few have high schools degrees. Another reason is related to how the labor is divided between sexes. Because of male immigration often the women of a family had took charge of garden and forest activities. Consequently, for those village women their working life has not changed with the coming of development. What has altered is the women's role in religious ceremonies and, gradually, in social life. With the spread of the nuclear family, opposite to the traditional extended family based on patrilocality, certain women, now have influence over their husbands 
more so than over their brothers or male relatives, in decisions regarding the use of forest land resources.

\section{Concepts of land ownership and impact of govern- ment policy}

New ideas concerning alternative uses of forest areas have surfaced in oksapmin areas in the past few decades: one of these has been timber production, although this kind of exploitation has not become a large scale industry due to the high costs of flying out the logs. Another change has been the introduction of new cash crops, even before the arrival of the mining companies, such as the adoption of pineapple, probably imported by Australian patrol officers (Australian kiap or OIC), in the 1960s.

The most important agents of communication through which new ideas of land ownership and use have entered the community have been outside workers, students and politicians.

The first category, the immigrants, is mainly composed of men between 20 and 40 years, working and living, alone or with their families, in the mine centers. They play a role of providing information, and are the main link between the village community and the urban, developed centre. Women are included in this category, sisters, wives, mothers, daughters of the mine workers often leaving with the men or visiting their relatives in town for several weeks, sometimes months. Nevertheless their role is less important than their male relatives' role.

The second category includes high school, college or university students. They are boys and girls between 15 and 25 years living in towns such as Vanimo or Lae. This is the category with the most recently educated people. They have been brought up to have competence and knowledge about development.

The third category is the most powerful in terms of influence. Provincial and national politicians belong to this category. They are all adult men, all initiated, who have lived through a fundamental historical and cultural period: the precontact era and the coming of Evangelization and protectorate administration until independence. They are competent in - and they benefit from - both cultures, the traditional customs therein and the globalization process. They went through initiation and know the traditional knowledge of their culture (which gives them a power similar to that of the traditional leaders) and have been educated in missionary and governmental schools.
The main communication media has been provincial and national radio stations. The radio is the only media with a notable presence in Oksapmin. One could find at least one radio in each parish or village section.

Information concerning governmental policy is obtained mainly by the OIC and the local politicians. But the rule of national institutions is still practiced as unilateral assistance. For example, the obligation to pay taxes to the government is generally avoided by several agriculturalists. This can be partly justified by the absence, or, inefficiency of governmental services. The Oksapmin Patrol Post, which began in 1961, has unofficially finished in the last few years. The public servants are motivated in their work, as they have very poor equipment and are often paid after several months of delay. For these reasons, when people talk about the government, the general feeling is one of betrayal.

As a result of all those concomitant causes, people of the Lagaip-Strickland area fear government involvement on the customary land, preferring to deal with private companies. They are particularly interested in establishing relations with mining companies, knowing that private companies are reliable.

\section{The Strickland river basin and related ritualism}

The Strickland river encompasses the North, East and South oksapmin areas ${ }^{2}$, constituting the Eastern ethnic and cultural boundary for the whole of the Min people. The oksapmin riverside of Strickland was the starting point of a paramount ritual in oksapmin culture.

The literature about the Afek mythical complex is rich and articulated all over the Mountain Ok ethnography (Barth, 1975; Bercovitch, 1989; Brumbaugh, 1980, 1990; Craig, 1964; Gardner, 1984; Jones, 1980; Jorgensen, 1981; Morren, 1986; Perey, 1973; Poole, 1976; Wheatcroft, 1976). Afek, or Yuan-ku in Oksapmin, came from the East and went Westward coming from the Highlands and proceeding towards Telefolmin, following the sun path. The other recurrent theme is the crossing of the Strickland (Umeng) river. The mythical existence of Yuan $k u$ in oksapmin cosmology is related to the Strickland river. Yuan $\mathrm{ku}$ created neither human and animal beings nor the environment but she transformed the entire cosmos and gave the people new cultural and ecological rules. Following the Yuan ku secret teachings, the oksapmin people learned to 
perform a fertility ritual based upon a human sacrifice.

The victim had to be taken into a clan indicated by Yuan ku, the Alipim clan, created by her, residing along the eastern range of the oksapmin region, after crossing the Strickland river. It is interesting to note that, in the Duna hambua narrative, Alipima is the name of an oksapmin man (Strathern, 1995a:7). The victim had to be a strong, young man of testified fertility, meaning he had to be married with at least one or more children. Being performed only once every several decades, it happened that often men did not take part in it during the course of their own life.

The aim of the Yuan cult was to insure fertility of the ground. Moreover, if one agrees with the hypothesis of the ipomoean genesis of the cult, the appearance of the cult occurred because of the introduction of the sweet potato. This new crop represented a remarkable wealth. In the more recent and tangible process of conversion to Christianity, the aim was to still obtain substantial influence helping them to acquire the white man's wealth. The Christian God took over the role of cosmogonical and ecological master which Yuan ku had in the past over the pre-existing cosmogonical beings. This process may also have been facilitated by certain formal parallels like the sacrifice of Yuan and that of Jesus Christ (in this sense see also Glasse, 1995: 58 regarding the Huli). The same process could have operated in the past. The Yuan cult may have played a part in substituting the previous cosmological explanation with a new one, represented by Yuan $k u$.

\section{Role of yester-years cosmology in present land ownership issues}

It is important to be aware of disappeared cosmologies and associated rituals in order to understand in what sense the role of yester-years beliefs play in current environmental representations. The rediscovery of the past becomes even more sensible to analyze since the oksapmin society is today fully converted to Christian religion. Why did the Oksapmin return to past, traditional cosmologies in order to deal with contemporary issues imported by foreign companies? Why are the oksapmin traditional cosmological rituals so important in contemporary ecological and political issues? How can the ancient beliefs affect the way in which people create current representations of PJV presence and its impact on the river system?
The first remark is of a topographical kind. In oksapmin mythical and historical times, innovation came from the east, from the Highlands through the Strickland, following the sunrise. This was also the case of cosmological renewal brought by the old woman Afek, the «big mother » of all Min people. It was the case of the introduction of the sweet potato, which arrived to the oksapmin area from the Highlands through the Strickland. And it was the case of the first white $\operatorname{man}^{3}$ who accessed the area coming from the Highlands and crossing the Strickland. Later, in the sixties, the first missions who settled in the area had their headquarters in Mount Hagen. These details are important in order to understand why the effects of PJV on the Strickland river system operations, coming from East, had such a big impact on oksapmin cultural representations concerning the environment.

The river always had a cosmological value in oksapmin culture. In oksapmin narrative there is no myth detailing the origins of the Strickland river but it is believed to be the origin of the wild pigs. The wild pigs were generated by a mythical animal called sip. This mythical creature is described as quadruple the size of a cow and is sometimes called «water buffalo ». Indeed this appellation could be misleading. People said that the sip did not have horns like buffalos but had tusks like wild pigs. Archaeological and zoological data led us to advance the hypothesis that the sip may be the oral reminiscence of the extinct marsupial, Huliterium Thomasetii. This mythical animal was the "father » of wild pigs, the spirit from whom wild pigs originated.

Evangelized Oksapmin returned to this preChristian belief saying that the sip have been killed by chemical pollution and consequently the presence of wild pigs towards the Strickland riverbanks grassland area is nowadays so scarce. People not only want to be compensated for the ecological impact of PJV presence in the area but more importantly for the profanation of their sacred spirits and the violation of ritual sites. Some may say that contemporary evangelized oksapmin people have ceased to follow ancient rituals and no longer believe in traditional cosmology. But the contemporary situation in Oksapmin is much more complex than this and can not be reduced to the dualistic opposition of present/past, traditional beliefs/Evangelization. The conversion to Western religion has been a superficial process materially oriented through which the traditional cosmological infrastructure has been consciously removed in order to 
introduce the new cosmology. The traditional beliefs have not entirely disappeared, but have been hidden from the sight of pastors and the « white man » in general, who are supposed to follow the same corpus of religious tradition. Practice of sorcery, witchcraft, divination and garden magic are still alive as they have a deeper existence in the social and cultural history and cannot be washed away in a couple of generations. If the ceremonial and spirit houses have been rushed away under pressure from missionaries, if initiations have been forbidden, this only represents the tip of the iceberg which has risen to the surface. Nevertheless an enormous corpus of traditional beliefs still takes place in everyday life. Their cultural heritage has not been erased by a forced process of conversion in a couple of decades. It has just been modified and adapted to the changed external constraints due to the arrival of the newcomer cosmology : Christianity.

Oksapmin people who converted to Christianity are rediscovering river spirits and sacral sites to enable them to play a role in the claims for land rights. These had been fundamental elements in previous generations, and that is why the spiritual significance of the Lagaip and the Strickland river in indigenous culture has to be taken into account and people have to be compensated for cultural as well as ecological damages to their environment.

Chemical pollution killed the "wild pig's father " whereas erosion washed away the signs of the passage of the " great mother ». She arrived to Oksapmin crossing the Strickland and it was on the riverbanks that people started the cyclical Yuan-täl ritual of thanks to Afek (Yuan$k u$ ) for having civilized them. Several ritual sites, whose function remains secret, have been washed away by erosion. The disappearance of the sacred sites will not seriously compromise the land rights in the oksapmin community since concern based on oral tradition survives in oksapmin people. But oral tradition is due to collapse quite fast because of the cultural and social changes and primarily, because of the end of male initiations.

Taking another example : fishing by hook was traditionally a secret ritual in Oksapmin carried out by initiated men. This ritual was taught to boys during the initiations. Several clans living close to the riverbanks were specialized in this kind of sacred fishing. In the oksapmin ethnonymy there is a distinction between people living close to the river banks and more distant ones living up in the mountains. The people of Kunanap, Duban, Sisimin are called um-hän literally «people who live down below» whereas the mountain people are called as- hän literally « people who live on the top ». The difference is verbalized mainly concerning access to the different natural resources. The um-hän (lowlands) people have marita pandanus, cassowaries, wild pigs, wild fowl and fish. The as-hän (mountain) people have karuka pandanus and possums. Only the um-hän people or their related clans were able to perform " magic fishing » by using hooks. It was said that during the sixties oksapmin elders witnessed patrol officers and policemen fishing by hook along the riverbanks in front of women and children, who were scared about the breaking of this secret knowledge.

The fish meat was cooked and eaten. The fish bones were used in a magic act to make domestic pigs grow fat. Once more, the fish, a constitutive element of the riverine eco-system, was used in relation with essential keys of subsistence like raising pigs. People complain that chemical pollution has killed fish, which were used to give power and health to domestic pigs.

Finally, the entire pig population has been symbolically affected by riverine impact. The father of the wild pigs, the sip spirit, has died and the wild pigs are no longer found around the Strickland. The magic ingredient of wealth of the domestic pigs, i.e. the fish bones, have been killed through chemical pollution consequently the domestic pigs look unhealthy nowadays.

Considering all these damages one may think that the ecological impact of PJV operation on the Lagaip-Strickland riverine system may be exploited to justify most of the problems in the Strickland basin. This is not the case because we must think about the ecological impact in the broader frame of shifting technologies. From this point of view, each ecological modification more than on an empirical basis is also interpreted on an ideological one.

The impact of mining operations on the sacred sites, provoked a resurgence of oksapmin traditional cosmologies. In that context the ground and, in a broader sense, the earth, find again their original importance. The sacred sites are re-interpreted and perceived as the guardians of land rights, held by mythical actors at the beginning of time.

Moreover coming back to traditional issues to claim ethnic unity and homogeneity ("we must be compensated as Oksapmin, as a whole people and not just as individuals landowners") it's a social strategy to counterpoise an autochthonous sense of identity built on notions of common origins, mutuality, co-ritualism and co-ownership, to a western sense of private pro- 
perty based on individuality and exclusion of everybody but the landowners.

\section{BIBLIOGRAPHY}

BARTH Fredrick, 1975. Ritual and Knowledge among the Baktaman of New Guinea, Yale University Press, New Haven.

Bercovitch Eytan, 1989. Disclosure and Concealment: A Study of Secrecy among the Nalumin People of Papua New Guinea, Ph D Thesis, Stanford University.

Brumbaugh Robert, 1980. A Secret Cult in the West Sepik Highlands, Ph D Dissertation, State University of New York at Stonybrook.

—, 1990. A Secret Cult in the West Sepik Highlands, in Craig B. and D. Hyndman (eds), Children of Afek. Tradition and Change Among the Mountain Ok of Central New Guinea. Sydney, University of Sydney, Oceania Monograph 40.

BRUTTI Lorenzo, 1997. Waiting for God. Ecocosmological Transformations among the Oksapmin in Strathern, Andrew and Stewart, Pamela (ed.) Millennial Markers in the Pacific. Townsville : Center for Pacific Studies, James Cook University of North Queensland.

CraIG Barry, 1964. Oksapmin Initiation Cycle, Unpublished field notes on Oksapmin Culture, Port Moresby, UPNG Library.

GARDNER Donald, 1984. A Note on the androgynous qualities of the Cassowary: or why the Mianmin say it is not a Bird, Oceania 55 (2), pp. 137-145.
Glasse Robert M., 1995. Time Belong Mbingi: Religious Syncretism and the Pacification of the Huli, in Biershak, Alietta Papuan Borderlands, Ann Arbor, University of Michigan Press.

Jones Barbara, 1980. Consuming Society: Food and Illness among the Faiwol, PhD Dissertation, University of Virginia.

JORGENSEN Dan, 1981. Taro and Arrows: order, entropy and religion among the Telefolmin, $\mathrm{PhD}$ Dissertation, University of Western Ontario.

Morren George E.B., 1986. The Myanmin. Human Ecology of a Papua New Guinea Society, Ann Arbor, UMI Research Press, Studies in Social Anthropology 9.

Perey Arnold, 1973. Oksapmin Society and World View, Ph D Thesis, Anthropology, Columbia University.

Poole Fitz John Porter, 1976. The AIS AM: an Introduction to Male Initiation Ritual among the BiminKuskusmin of the West Sepik District, Papua New Guinea, Ph D Thesis, Anthropology, Cornell University.

Strathern Andrew J., 1995. Sacrifice and Sociality: A Duna Ritual Track, Paper presented to the conference Importing Cultures: Regional Transformations in Myth and Ritual in the Western Highlands of Papua New Guinea, University of Queensland.

Wheatcroft Wilson G., 1975. The Legacy of Afekan: Cultural symbolic Interpretations of Religion Among the Tifalmin of New Guinea, Ph D Dissertation, Chicago. 